\title{
Effect Of Exports, Government Expenditure And Inflation On Indonesia Poverty (2000-2019)
}

\author{
Anas Fadhillah \\ Faculty of Economics and Business, Universitas Jenderal Soedirman, Indonesia \\ anasfadhillah.af@gmail.com \\ Arintoko \\ Faculty of Economics and Business, Universitas Jenderal Soedirman, Indonesia \\ arintokoz@yahoo.co.id

\section{Kamio} \\ Faculty of Economics and Business, Universitas Jenderal Soedirman, Indonesia \\ kamio_ep_feunsoed@yahoo.com
}

\begin{abstract}
The purpose of this study to analyze the effect of exports, government expenditure, and inflation on poverty in Indonesia in 2000-2019, and the independent variables which are the most dominant against poverty in Indonesia. The data used are secondary data taken from Bank Indonesia and Badan Pusat Statistik (BPS). This study uses a regression method with the OLS (Ordinary Least Square) model. or the ordinary least squares model. The results of this study note that oil and gas and non-oil exports have a negative and significant effect on poverty, government expenditure has a significant and negative effect on poverty, and inflation has a positive but not significant effect. To reduce poverty in Indonesia, it is necessary to export commodities that have a large added value, government expenditure which leads to a reduction in the number of poor people, and to control prices of goods and services that are stable / accessible to the poor.
\end{abstract}

Keywords: Poverty, exports, government expenditure and inflation

\section{INTRODUCTION}

Poverty is one of the economic problems faced by all countries in the world and has become a phenomenal problem which has become a reference point for the success of the country from time to time, every country strives to reduce poverty, especially in developing countries.

Indonesia is a developing country that pays attention to the problem of poverty and makes every effort to reduce the number of poor people. Various policies, strategies and activities to reduce poverty, both directly and indirectly, have been implemented at regional and national scales.

Poverty is caused due to a condition in which the inability to meet basic needs such as food, clothing, shelter, health and education. This is due in part to the increase in the price of goods and services that the public cannot afford continuously or what is often called inflation (Samuelson dan Nordhaus, 2004).

The root of the problem of poverty is related to national output which is known to be in deficit in international trade activities, import value is greater than export value, low export value results in low national output, low national output cannot create new jobs while the population is increasing, the number of people who do not have a job then there is unemployment, people do not have income to make ends meet and poverty occurs. Indonesian exports still rely on raw material products that still have little added value. 
Tabel 1. Indonesian Raw Material Exports 2015-2019

\begin{tabular}{lclcc}
\hline & \multicolumn{4}{c}{ Exports ( Thousand Ton) } \\
\cline { 2 - 5 } Years & Crude petroleum & Palm oil & Coffee & Raw rubber \\
2015 & $\mathbf{1 5 5 5 4}$ & $\mathbf{2 7 6 7 0}$ & $\mathbf{4 9 9 6 1 2}$ & $\mathbf{2 5 4 3}$ \\
2016 & $\mathbf{1 6 9 5 5}$ & $\mathbf{2 4 0 6 6}$ & $\mathbf{4 1 2 3 7 0}$ & $\mathbf{2 4 9 4}$ \\
2017 & $\mathbf{1 3 5 7 0}$ & $\mathbf{2 8 7 7 0}$ & $\mathbf{4 6 4 1 9 8}$ & $\mathbf{2 9 2 2}$ \\
2018 & $\mathbf{1 0 2 1 4}$ & $\mathbf{2 9 3 0 2}$ & $\mathbf{2 7 7 4 1 1}$ & $\mathbf{2 7 4 2}$ \\
2019 & $\mathbf{3 5 7 6}$ & $\mathbf{2 9 5 4 7}$ & $\mathbf{3 5 5 7 6 6}$ & $\mathbf{2 4 4 0}$ \\
\hline
\end{tabular}

Sources: Badan Pusat Statistik

Government expenditure is not optimal for alleviating poverty, and prices for goods and services that are not accessible to the community. The problem of poverty demands government intervention. The government has carried out several development policies maximally to reduce the number of poor people, improving education has also been found to be a key factor in poverty alleviation (Gokan, 2011). However, in fact, until now this problem has not been completely resolved. Economic development seeks to achieve sufficiently high economic growth, and in the end it enables the realization of an increase in the standard of living and welfare of the people. Several countries have implemented strategies to increase the rate of economic growth to reduce the number of poor people. With government intervention, it is hoped that the problem of poverty can be overcome. The public has heard and felt the intervention of the government at both the national and regional levels, for example in every election campaign there is always a poverty reduction program plan, which has also been carried out by the government. Direct poverty reduction can be carried out by providing the Family of Hope Program, food assistance, cash and non-cash assistance, while indirect poverty reduction is the Healthy Indonesia Card (KIS), BLT, Raskin, BOS, Smart Indonesia Card (KIP), labor-intensive work programs and others.

The phenomenon of inflation indicates that there is a change and growth in the economy, both micro and macro that have an effect on other economic performance. Inflation can be defined by an increase in the price of goods in general and continuously means that the phenomenon of an increase in the price of goods occurs in most of the goods on the market.

In a healthy economic structure, the burden of inflation affects almost the entire population, even though the heaviest bearers of inflation are the people with fixed income and the unemployed (who have no income). A spike in inflation that is too high and is not balanced by economic equality will expand poverty, increase the unemployment rate, and will lead to poverty.

Research on poverty has been carried out by many economists, but what distinguishes this research from previous research is the aspect of using macroeconomic variables and the current period, namely in the reform era, this study uses the latest period variables, namely 2000-2019.

\section{LITERATURE}

\section{Poverty}

Poverty is an individual's inability to meet his basic needs for a better life. Poverty is a condition which is below the poverty line. Poverty is generally defined as income in the form of money plus the nonmaterial benefits that a person gets (Agus Sjafari, 2014: 16). Poverty can also be measured by comparing the level of consumption of a person with the poverty line or the amount of money spent on people's consumption per month, including the poor if the average monthly expenditure is below the poverty line.

\section{Export}

Export activity is a trading system by means of removing goods from within the country out of the country in compliance with applicable regulations. Exports are the total goods and services sold by a country to another country, including goods, insurance, and services in a given year. Sutedi (2014:7).

The balance of payments is a record of economic transactions between residents of Indonesia and non-residents for a certain period. The balance of payments of a country is said to be a surplus if there is an excess of trade and investment funds compared to the obligations paid to the state, while it is said to be a deficit if imports are greater than exports. The state of the balance of payments that is surplus or deficit affects Indonesia's economic growth. 


\section{Government Expenditure}

Government consumption expenditure, which is commonly called government expenditure, includes all expenditures that the government directly or indirectly receives in return for services. Meanwhile, according to (Sukirno S, 2016) Government spending is part of fiscal policy, namely a government action to regulate the running of the economy by determining the amount of government revenue and expenditure each year, which is reflected in the National State Budget (APBN) document and the Revenue Budget. Regional Expenditures (APBD) for regions or regions.

\section{Inflation}

Inflation is a condition caused by an unbalance between demand for goods / services and supply, i.e. demand exceeds supply and the greater the difference, the greater the danger posed by inflation for economic activity. Inflation occurs when the process of price increases takes place continuously and affects each other. And if the income level of the population is very limited, while inflation is unstable, many poor households are forced to change their basic diet to the cheapest goods with a reduced number of goods (Mehmood and Sara, 2010). In addition, inflation also has a positive side, inflation is needed to increase the enthusiasm of entrepreneurs to benefit from their business activities, however, a good price increase is a stable increase in prices.

\section{METHOD}

This research is a quantitative research because it refers to the calculation of the analysis of research data in the form of numbers or qualitative data which are extrapolated. According to Sugiyono (2013: 12) the quantitative research method is a research method in the form of numbers and the analysis uses statistics.

Based on the data source, this study uses secondary data. Secondary data sources are data sources that do not directly provide data on data collection, data can be obtained from institutions or agencies (Sugiyono, 2013: 402). The data needed in the research are all the variables studied include the number of poor people, oil and gas and non-oil and gas exports, government spending and inflation in Indonesia in 2000-2019. In this study using time series data model OLS (Ordinary Least Squares). The OLS model method is appropriate for this study because this study analyzes to determine the one-way effect of the independent variables (inflation, government spending, gross domestic product, and foreign debt) on the dependent variable (poverty) in the long run. the regression model is as follows:

POVERTYt $=\beta_{0}+\beta_{1} E k s+\beta_{2} G E+\beta_{3} \operatorname{Inf}+\mathrm{e}$

Explanation:

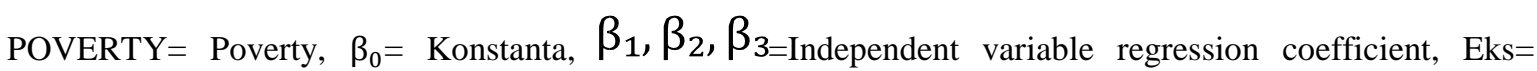
Exports 2000-2019, GE= Government Expenditure 2000-2019, Inf= nflation in 2000-2019, $\mathrm{t}=$ unit time series, e = error

In order for the model to provide the best estimation results or BLUE (Best Linear UnPure Estimator), the model must meet classical linear regression, which means that there are no symptoms of multicollinearity, autocorrelation, and heterocedasticity. After the proposed model is BLUE, to achieve the first research objective it is necessary to carry out the classical assumption test, the F test and the T test.

\section{RESULTS AND DISCUSSION}

To determine the effect of exports, government spending, and inflation on Indonesian poverty in 2000-2019, multiple regression analysis of time series data is used. Exports, government spending, and inflation are independent variables and the number of poor people is the dependent variable. From the above tests it can be seen: 
Table 2. Results of the Analysis of the Effects of Exports, Government Spending, Inflation, and Unemployment on Indonesian Poverty

\begin{tabular}{lrrrr}
\hline Variable & Coefficient & Std. Error & t-Statistic & Prob. \\
\hline C & 39636964 & 1301565 & 30.4533 & 0 \\
EXPORT & -23.52678 & 1.091607 & -2.15524 & 0.0467 \\
GE & -4.255606 & 7.915765 & -5.3673 & 0.0001 \\
INF & 166016.8 & 102629.4 & 1.617634 & 0.1253 \\
\hline
\end{tabular}

POVERTYt $=39636964-23.52678($ Eks $)-4.255606(\mathrm{GE})+166016.8($ Inf $)+\mathrm{e}$

The result show that, when there is an increase in oil and gas and non-oil and gas exports by 1 million US \$, it will reduce the number of poor people by 23,52678 people and vice versa. Exports as one of the drivers of economic growth indicate a growing number of national output, indicating that many people are working and the poverty rate is low. One of the drivers for economic growth is international trade, the goal of a country that imports / exports is to improve the welfare of that country.

International trade is a major contributor to Indonesia's foreign exchange reserves. This surplus can be achieved through the difference between the volume of exports and imports obtained in the trade balance. The strengthening of foreign exchange reserves is also inseparable from the influence of the exchange rate, therefore it is necessary to pay attention to the stability of the exchange rate in order to help stabilize the economy and support the expansion of exports so as to achieve better prosperity. It is as effective as possible to learn from outside industries in order to achieve maximum results and be able to compete in foreign markets (Safitri, 2014).

Furthermore, when there is an increase in government spending by 1 rupiah, it will reduce the number of poor people by 4,255606 people and vice versa. The results of this analysis are also confirmed by Alshahrani and Alsadiq (2014), who support the Keynesian view that states the importance of the role of government for development. In this case, the government through fiscal policy in the form of direct spending or indirect spending stimulates national economic growth and poverty alleviation (Ogundipe \& Oluwatobi 2013; Folster \& He-nrekson 2001). These results also support the idea that the role of the government of Harrod-Domar in creating economic growth is not only short-term, but also has a long-term perspective (Wahyu et al. 2014; Hussein and Thirlwall 2000).

Inflation increases by 1 percent, it will increase the number of poor people by 166016.8 people and vice versa. This is in accordance with economic theory, when the prices of goods and services experience an extreme increase resulting in people unable to reach prices, people cannot meet their basic needs.Test $\mathrm{R}^{2}$. The economic problems faced by developing countries, including Indonesia, are related to problems of poverty, unemployment and inflation. This is a dilemma for developing countries. One of the unresolved problems in Indonesia is the problem of poverty. Poverty alleviation is a major policy goal in developing countries. (Cuong, 2011).

\section{Multicollinearity Test}

The multicollinearity test results can be seen in the Centered VIF column table. VIF values for the variables Ex (3.521543), GE (4.043798), Inf (1.4687). Because none of the VIF value of the variable is greater than 10, it can be said that there is no multicollinearity in the independent variable. Based on the classical assumption requirements of linear regression with OLS, a good linear regression model is one that is free from multicollinearity. Thus, the above model is free from multicollinearity.

\section{Autocorrelation Test}

Prob Value. F (2.14) of 0.02453 can also be referred to as the calculated F probability value. Prob Value. F count is greater than the alpha level of $0.05(5 \%)$ so, based on the hypothesis test, H0 is accepted, which means there is no autocorrelation. Conversely, if the value is Prob. F count is less than 0.05, it can be concluded that autocorrelation occurs.

\section{Normality Test}

The decision is normally distributed whether residuals are simple by comparing the probability value of JB (Jarque-Bera) calculated with an alpha level of 0.05 (5\%). If Prob. JB count is greater than 0.05 , 
it can be concluded that the residuals are normally distributed and vice versa, if the value is smaller, there is not enough evidence to state that the residuals are normally distributed. Prob Value. JB count is 2.555086> 0.05 so it can be concluded that the residuals are normally distributed, which means that the classical assumptions about normality have been fulfilled.

\section{Heteroscedasticity Test}

Heteroscedasticity occurs when the residual and predictive values have a correlation or relationship pattern. This pattern of relationship is not only limited to a linear relationship, but in different patterns it is also possible. Therefore, there are several heteroscedasticity test methods that are owned by EViews, such as: Breusch-Pagan-Godfrey, Harvey, Glejser, ARCH, White and others. In this study using the Glejser test.

The decision whether or not heteroscedasticity occurs in the linear regression model is to look at the Prob Value. F-statistic (F count). If the value for Prob. F count is greater than the alpha level of 0.05 (5\%), it means that there is no heteroscedasticity, whereas if the value of Prob. F count is smaller than the alpha level of $0.05(5 \%)$ which means heteroscedasticity occurs. Prob Value. F count of 0.2513 is greater than the alpha level of $0.05(5 \%)$ so, based on the results above, it means that there is no heteroscedasticity.

\section{Model Feasibility Test}

\section{Simultaneous Significance Test (Test F)}

The basic F statistical test shows whether all the independent variables included in the model have a joint or simultaneous influence on the dependent variable, which is the initial step in identifying the regression model that is estimated to be feasible or not. Eligible, by means of which the estimated model is suitable to be used to explain the effect of the independent variables on the dependent variable. If after testing the prob value. F count is smaller than the error rate (alpha) 0.05 (which has been determined), it can be said that the estimated regression model is feasible, whereas if the value is prob. F count is greater than the error rate of 0.05 , it can be said that the estimated regression model is not feasible.

The results of the F test can be seen in the table above. The prob value. F (Statistic) of 0.000005 is smaller than the significance level of 0.05 so it can be concluded that the estimated regression model is suitable to be used to explain the effect of Export (Exs), Government Expenditure (GE), Inflation (Inf) and Unemployment (Unemployment) on the dependent variable. Poverty (Poverty).

\section{$\mathbf{R}^{2}$ Test}

The coefficient of determination explains the variation in the influence of the independent variables on the dependent variable. The R-Square value in the table above is 0.937948 which shows that the proportion of the influence of the variable Export (Ex), Government Expenditure (PP), Inflation (INF) on Poverty (Poverty) is $93.79 \%$ meaning that exports, government spending, and inflation have the effect on the amount of national savings is $93.79 \%$, while the remaining $6.21 \%$ is influenced by other variables.

\section{Partial Test}

Partial test is used to determine whether individually / partially the independent variable affects the dependent variable. Partial test using the $\mathrm{t}$ test statistic. The partial test results are as follows:

Table 7. Partial Test Result

\begin{tabular}{cl}
\hline Variabel & Prob. \\
\hline C & 0.0000 \\
Export & 0.0467 \\
GE & 0.0001 \\
Inf & 0.1253 \\
\hline
\end{tabular}

The variables that have a significant effect are exports and government spending, while the inflation variable has no significant effect. This is because the p-value of partial test results for all variables is less than alpha 0.05 and $v$ for the inflation variable is declared insignificant because it is more than 0.05 .

Based on the results of the analysis above, it can be seen that the export variable both in the long and short term has a negative and significant effect on poverty in Indonesia, this is because exports make a large 
contribution to poverty in the observation period. Export performance in this period can be said to be good where the number of requests for oil and gas and non-oil and gas goods and services abroad, bringing in foreign exchange, the domestic industry develops its factories then opens new jobs for the poor and makes the poor prosperous.

The improvement in export performance against poverty was due to the relaxed export bureaucracy system, which initially made strict regulatory requirements easier for export activities, and because the quality of exported goods and services was getting better and more trusted by export destination countries such as countries in the continent of Africa, Asia, Europe and Australia.

The results of the partial test on government spending on poverty have a negative and significant effect, this can be seen from the probability value of the government expenditure variable of 0.0001 , indicating that in the long term government spending has a significant effect on poverty. This research is in line with research conducted by Adi Widodo et al. (2011) that state spending / government expenditure has a negative and significant effect on poverty. Poverty occurs because of various problems and requires government intervention through poverty alleviation programs including government spending to increase the Human Development Index (HDI), this increase in HDI is accompanied by poverty reduction.

Government made a lot of expenses to finance its activities. The expenditure is not only for running the daily wheels of government, but also for financing economic activities. This does not mean that the government is involved in doing business, but the government must contribute to stimulating and stimulating economic activity in general, including poverty reduction so that it does not get worse and can be reduced. Government spending is divided into two central government expenditures and local government, this is done to make the efficient use of fiscal funds. There are several basic principles so that the implementation of fiscal decentralization can spur economic growth, including: First, local governments tend to be more efficient in providing and distributing public goods that have less extensive externalities, while for Public goods that cover the interests of the community are very broad and include cross-regional, better provision of them by the central government because if they are decentralized, they will cause inefficiency. In addition, it is necessary to pay attention to economies of scale in the provision of these public goods. This means that it is necessary to have a good arrangement regarding the affairs that fall under the authority of the central and regional governments.

In theory, inflation is an increase in the prices of goods and services in general at a certain time period, a fluctuating increase in the prices of goods and services causes the poor to not reach the prices of basic goods and services, based on the results of this study the inflation variable has a positive but insignificant effect on poverty. This can be seen in the results of the partial test which shows the regression result figure is greater than alpha 0.05 , which is 0.1253 , this is because the inflation variable is not the only factor causing poverty. According to Nurkse's (1961) theory, poverty is caused by a vicious cycle of poverty, a vicious cycle of poverty is a series of forces that influence an existence in which a country will remain poor and will experience a difficult phase to get out of this condition. The existence of underdevelopment and underdevelopment of human resources (low education), market imperfections, and a lack of capital which causes low productivity. Then low productivity results in low income, low income will have implications for low capital accumulation so that the job creation process is low (reflected by the high number of unemployed) and low capital accumulation is caused by underdevelopment and onward rotation.

\section{CONCLUSION}

The conclusion that can be drawn in this study is that oil and gas and non-oil and gas exports have a negative and significant effect on poverty in the 2000-2019 period, government spending has a negative and significant effect on poverty in the 2000-2019 period, and inflation has a positive and insignificant effect on Indonesian poverty in the 2000 period. -2019. Exports are the most influential variable on Indonesian poverty in the 2000-2019 period.

Based on the results and discussion of this research, several suggestions are put forward to the government and related agencies to maximize export-related policy making, such as expanding cooperation with foreign countries / companies, improving export quality, simplifying export regulations, and export policies that lead to poverty alleviation.

Government spending is more directed towards poverty alleviation programs either directly or indirectly. Inflation is a variable that has a positive effect on poverty, this is very important to pay attention to so that inflation is stable, Bank Indonesia and the Regional Inflation Control Team (TPID) are more concerned with monitoring extreme inflation symptoms. 
Subsequent research that examines research with the same topic as this study should examine more detailed variables, such as government spending on the education and health sectors, and add other variables such as government and private external debt or add to the period under study in order to provide maximum results.

\section{REFERENCES}

Alshahrani. SA \& Alsadiq. AJ (2014). Economic growth and government spending in Saudi Arabia: an empirical investigation ${ }^{e .}$ IMF Work-ing Paper. International Monetary Fund.

Cuong, N. V., (2011). Poverty projection using a small area estimation method: Evidence from Vietnam. Journal of Comparative Economics, 39(3), p. 368-382.

Gokan, Y., (2011). Poverty traps, the money growth rule, and the stage of financial development. Journal of Economic Dynamics and Control, 35(8), p. 1273-1287.

Loizides. J \& Vamvoukas. G (2015). Government expenditure and economic growth: evidence from trivariate causality testinge ${ }^{e}$. Journal of Ap-plied Economics. Vol. 8. No. 1. pp. 125-152.

Mehmood, Rashid. and Sara Sadiq. (2010). The Relationship between Government Expenditure and Poverty: A Cointegration Analysis. Romanian Journal of Fiscal Policy Volume 1. Issue 1. July-December 2010. Pages 29-37.

Nurkse. Ragnar. (1961). Problems of Capital Formation in Underdeveloped Countries. Oxford University Press. New York.

Safitri, H. (2014). Analisis Neraca Perdagangan Migas Dan Non Migas Indonesia Terhadap Volatilitas Cadangan Devisa 2003-2013. Economics Development Analysis Journal, 3(2). https://doi.org/10.15294/edaj.v3i2.3843.

Samuelson, Paul A dan Nordhaus, William D. (2004). Ilmu Makro Ekonomi (gretta, Theresa Tanoto, Bosco Carvallo dan Anna Elly, penerjemah). (17 ed) Jakarta PT. Media Global Edukasi.

Sjafari Agus. (2014). Kemiskinan Dalam dan Pemberdayaan Kelompok. Yogyakarta : Graha Ilmu

Sugiyono. (2013). Metode Penelitian Pendidikan (Pendekatan Kuantitatif, Kualititatif dan R\&D). Bandung: Alfabeta.

Sukirno, Sadono. (2016). Makroekonomi Teori Pengantar Edisi Ketiga Cetakan ke-23. Jakarta: PT. Raja Grafindo Persada.

Sutedi Adrian. (2014). Hukum Ekspor Impor. Cetakan I. Jakarta: Raih Asa Sukses

Widodo Adi dkk. (2011). Analisis Pengaruh Pengeluaran Pemerintah Di Sektor Pendidikan dan Kesehatan Terhadap Pengentasan Kemiskinan Melalui Peningkatan Pembangunan Manusia Di Provinsi Jawa Tengah. Jurnal Dinamika Ekonomi Pembangunan. 1 (1), 40-41. 


\section{ATTACHMENT}

Attachment 1. Multicollinearity Test

Variable Centered VIF

\begin{tabular}{rr}
\hline C & NA \\
EXPORT & 3.521543 \\
GE & 4.043798 \\
INF & 1.4687 \\
\hline
\end{tabular}

Attachment 2. Autocorrelation Test

Breusch-Godfrey Serial Correlation LM Test:

\begin{tabular}{llll}
\hline F-statistic & 1.556373 & Prob. F(2,14) & 0.2453 \\
Obs*R-squared & 3.637928 & Prob. Chi-Square(2) & 0.1622
\end{tabular}

Attachment 3. Normality Test

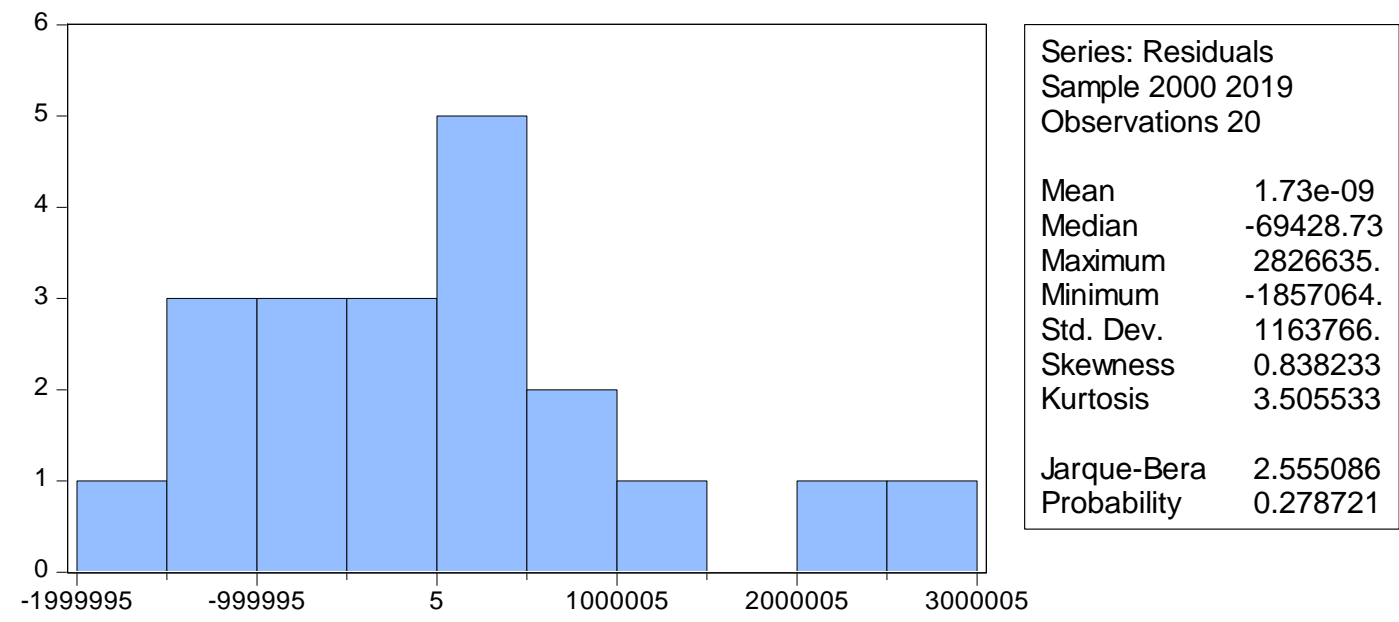

Attachment 3. Heteroscedasticity Test

\begin{tabular}{rlll}
\hline F-statistic & 1.505057 & Prob. F(3,16) & 0.2513 \\
Obs*R-squared & 4.401788 & Prob. Chi-Square(3) & 0.2212 \\
Scaled explained SS & 3.318505 & Prob. Chi-Square(3) & 0.3451
\end{tabular}


Attachment 4. Results of the Analysis of the Effects of Exports, Government Spending, Inflation, and Unemployment on Indonesian Poverty

\begin{tabular}{rrrrr}
\hline \multicolumn{1}{c}{ Variable } & Coefficient & Std. Error & t-Statistic & Prob. \\
\hline C & 39636964 & 1301565 & 30.4533 & 0 \\
EXPORT & -23.52678 & 10.91607 & -2.15524 & 0.0467 \\
GE & -4.255606 & 7.915765 & -5.3673 & 0.0001 \\
INF & 166016.8 & 102629.4 & 1.617634 & 0.1253 \\
R-squared & 0.937948 & Mean dependent var & 32541600 \\
Adjusted R-squared & 0.926314 & S.D. dependent var & 4671850 \\
S.E. of regression & 1268184 & Akaike info criterion & 31.12093 \\
Sum squared resid & 2.573213 & Schwarz criterion & 31.32007 \\
Log likelihood & -307.2093 & Hannan-Quinn criter. & 31.1598 \\
F-statistic & 80.6166 & Durbin-Watson stat & 1.44734 \\
Prob(F-statistic) & 0.00005 & & \\
\hline
\end{tabular}

